\title{
New Records of the Diatoms (Bacillariophyceae) from the Coastal Lagoons in Korea
}

\author{
Daeryul Kwon ${ }^{1}{ }^{(\mathbb{C}}$, Mirye Park ${ }^{1}\left(\mathbb{D}\right.$, Chang Soo Lee ${ }^{1}$, Chaehong Park ${ }^{2}$ and Sang Deuk Lee ${ }^{3, *(\mathbb{D}}$ \\ 1 Protist Research Team, Microbial Research Department, Nakdonggang National Institute of Biological \\ Resources (NNIBR), 137, Donam 2-gil, Sangju-si 37182, Korea; kdyrevive@nnibr.re.kr (D.K.); \\ mirye@nnibr.re.kr (M.P.); cslee@nnibr.re.kr (C.S.L.) \\ 2 Human and Eco-Care Center, Konkuk University, Seoul 05029, Korea; qkrcoghd@konkuk.ac.kr \\ 3 Bioresources Collection \& Research Team, Bioresources Collection \& Bioinformation Department, \\ Nakdonggang National Institute of Biological Resources (NNIBR), 137, Donam 2-gil, Sangju-si 37182, Korea \\ * Correspondence: diatom83@nnibr.re.kr; Tel.: +82-54-530-0898; Fax: +82-54-530-0899
}

Citation: Kwon, D.; Park, M.; Lee, C.S.; Park, C.; Lee, S.D. New Records of the Diatoms (Bacillariophyceae) from the Coastal Lagoons in Korea. J. Mar. Sci. Eng. 2021, 9, 694. https://doi.org/10.3390/ jmse9070694

Academic Editors: Wonho Yih, Milva Pepi and Magnus Wahlberg

Received: 1 May 2021

Accepted: 16 June 2021

Published: 24 June 2021

Publisher's Note: MDPI stays neutral with regard to jurisdictional claims in published maps and institutional affiliations.

Copyright: (c) 2021 by the authors. Licensee MDPI, Basel, Switzerland. This article is an open access article distributed under the terms and conditions of the Creative Commons Attribution (CC BY) license (https:// creativecommons.org/licenses/by/ $4.0 /)$.

\begin{abstract}
Lagoons are natural bodies of water that are isolated from the sea due to the development of a sand bar or spit. Each lagoon has distinct ecological characteristics, and these sites also serve as popular tourist attractions because they are common habitats for migratory birds and are characterized by beautiful natural scenery. Lagoons also have distinct ecological characteristics from those of their associated estuaries, and there are active research efforts to classify, qualify, and quantify the high biodiversity of lagoons. The lagoons in Korea are primarily distributed in the East Sea, and are represented by Hwajinpo, Yeongrangho, and Gyeongpoho. Here, we report the discovery of 11 unrecorded diatom species (Diploneis didyma, Mastogloia elliptica, Cosmioneis citriformis, Haslea crucigera, Pinnularia bertrandii, Pinnularia nodosa var. percapitata, Gyrosigma sinense, Gomphonema guaraniarum, Gomphonema italicum, Navicula freesei, Trybionella littoralis var. tergestina) among samples collected from the Hwajinpo, Hyangho, Maeho, Gapyeongri wetland, Cheonjinho, and Gyeongpoho lagoons in Korea during a survey from 2018-2020. We present the taxonomic characteristics, ecological information, habitat environmental conditions, and references for these 11 species.
\end{abstract}

Keywords: lagoon; new record diatoms; taxonomic; ecological; habitat

\section{Introduction}

Lagoons are a form of riparian terrain where the river and sea water meet, but they have unique ecological characteristics that distinguish them from estuaries because, in lagoons, the entrance to the coast is blocked by sand dunes [1,2]. The lagoons distributed along the Korean coast are known to have been formed by a combination of rising sea levels during the postglacial age and the development of sandbars or sand dunes [3,4].

The East Sea coast boasts the cleanest marine environments in Korea and is blessed with natural resources to sustain the area. There are 18 lagoons distributed along a $112 \mathrm{~km}$ stretch of the East Sea coast [5]. These lagoons provide beautiful natural scenery and have unique ecological value with their brackish water lakes, important migratory bird habitats, and are also economically valuable as tourist attractions [4,6].

Hwajinpo Lake is the largest lake in Korea with a circumference of $16 \mathrm{~km}$ and is a typical high-salinity brackish lake with a high ecological value [4,7]. Hyangho Lagoon hosts a community of aquatic plants covering approximately $20 \%$ of its area. It belongs to a heavily landlocked lake, and, unlike other lagoons, freshwater lakes are distributed behind it, serving as a sheltered habitat for organisms living in the lake [8]. Cheonjinho Lake's characteristic brackish water has disappeared due to the blocked inflow of seawater; it has a wide variety of free-floating and floating-leaved plants, and a high proportion of aquatic and wetting plants $[9,10]$. Gyeongpoho is the representative lagoon of the East Sea coast for the endangered prickly waterlily, Euryale ferox, which appeared 40 years ago and is 
known as a favored habitat for various migratory birds [11,12]. The Maeho lake has a high ecological conservation value due to its diverse distribution of biological resources and ecosystem services, such as being designated as a cultural heritage reserve. However, the lake area is decreasing due to the nearby expansion of farmland and subsequent soil erosion, causing sedimentation [4]. Gapyeongri wetland is one of the smallest lagoons, well-hidden behind a widely developed coastal sand dune [13]. Yeomgaeho Lake is also small, but is a typical natural lagoon, suitable as a migratory bird habitat; however, land reclamation is occurring rapidly in the area [13]. Regardless, the lagoons are worthy of research because they have ecologically diverse characteristics and high biodiversity $[14,15]$.

Diatoms are recognized worldwide as one of the most suitable biological components for water quality assessments because they continuously occur in aquatic ecosystems and respond quickly to environmental changes $[16,17]$. Diatoms can occur wherever there is water, can attach to all substrates, such as gravel and plants, and can live in various water environments $[18,19]$. However, research on diatoms in lagoons is poor. Even though data from low-salinity environments are readily available, those from high-salinity environments are limited [20].

There are many reports of new and unrecorded diatoms in Korea [21-23]. Species collected in environments such as lagoons, estuaries, and sedimentary soils with unique habitats other than freshwater environments are being reported [23-25].

In this study, we describe taxonomic information on 11 previously unrecorded diatom species found in six lagoons in Korea, and provide details on the ecological characteristics, reference specimen, basionym, synonym, and distribution of each.

\section{Materials and Methods}

\subsection{Collecting and Fixation of Samples}

Samples were collected from six lagoons: Hwajinpo, Hyangho, Maeho, Gapyeongri wetland, Cheonjinho, and Gyeongpoho, adjacent to the East Sea in Korea from 2018-2020. The epilithic diatoms were scraped off the upper surface of the gravel using a small chisel or toothbrush. The collected wild cells were immediately fixed with Lugol's solution (iodine-iodide solution), 4\% neutralized formalin, or $2 \%$ glutaraldehyde [26]. Environmental parameters such as water temperature $\left({ }^{\circ} \mathrm{C}\right), \mathrm{pH}$, dissolved oxygen $(\mathrm{mg} / \mathrm{L})$, electric conductivity $\left(\mu \mathrm{s} / \mathrm{cm}^{3}\right)$, and salinity (PSU) were measured using a portable multiparameter water quality meter (Pro DSS, YSI, Yellow Springs, OH, USA) in the field.

\subsection{Pretreatment and Observation of Diatoms}

To remove organic matter, the fixed samples were boiled in equal amounts of mixed $\mathrm{HCl}$ and $\mathrm{KMnO}_{4}$ at $70{ }^{\circ} \mathrm{C}$ until the samples were slightly colored, and were then rinsed in distilled water to remove residual acid, following a modified method of Hasle \& Fryxell [27]. The samples were then rinsed in distilled water to remove any residual acid. The samples, some fixed and some cleaned, were mounted in Pleurax (Mountmedia, Wako, Japan) for observation using a light microscope (LM) (Eclipse Ni; Nikon, Tokyo, Japan), equipped with Nomarski differential interference contrast optics (DIC) and a digital camera (DS-Ri2; Nikon, Tokyo, Japan). In addition, the morphological characteristics of various foci on the valve face on Mastogloia elliptica were observed with a microscope.

The terminology was according to that of Anonymous [28], Ross et al. [29], and Round et al. [30].

\section{Results}

\subsection{Identification of Diatom Species in Korean Lagoons}

A total of 11 previously unrecorded diatom species were identified from the six lagoon sites surveyed in this study (Figure 1). Two species each belonged to the genera Gomphonema and Pinnularia, with one species represented by the genera Diploneis, Mastogloia, Cosmioneis, Haslea, Gyrosigma, Navicula, and Tryblionella, respectively. According to site, four of the unrecorded species (Mastogloia elliptica, Cosmioneis citriformis, Haslea crucigera, and Pinnularia 
bertrandii) were detected at Hyangho, the two Gomphonema species (G. guaraniarum and G. italicum) were detected in the Gapyeongri wetland, and two species (Navicula freesei and Tryblionella littoralis var. tergestina) appeared in Yeomgaeho. One unrecorded species was, respectively, detected at Gyeongpoho (Diploneis didyma), Cheonjinho (Pinnularia nodosa var. percapitata), and Maeho (Gyrosigma sinense) (Table 1).

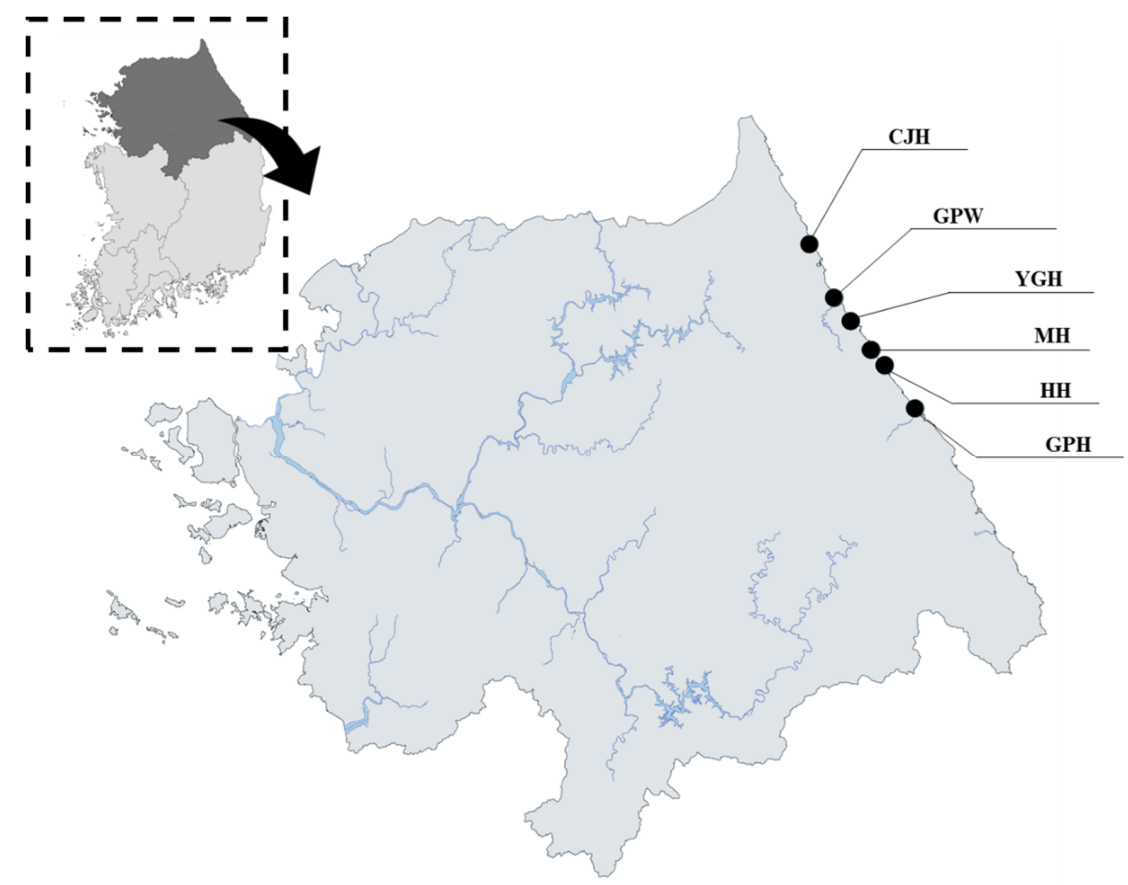

Figure 1. Sampling sites along the lagoons (CJH: Chunjinho, GPW: Gapyeongri wetland, YGH: Yeomgaeho, MH: Maeho, HH: Hyangho, GPH: Gyeongpoho).

Table 1. Information of sampling sites.

\begin{tabular}{|c|c|c|c|c|}
\hline Site & Location & Latitude (N) & Longitude (E) & Collected Species \\
\hline GPH & $\begin{array}{l}\text { Jeo-dong, Gangneung-si, } \\
\text { Gangwon-do }\end{array}$ & $34^{\circ} 47^{\prime} 32.43^{\prime \prime}$ & $128^{\circ} 53^{\prime} 48.89^{\prime \prime}$ & Diploneis didyma \\
\hline $\mathrm{HH}$ & $\begin{array}{l}\text { Hyangho-ri, Jumunjin-eup, } \\
\text { Gangneung-si, Gangwon-do }\end{array}$ & $37^{\circ} 54^{\prime} 35.2^{\prime \prime}$ & $128^{\circ} 48^{\prime} 22.2^{\prime \prime}$ & $\begin{array}{c}\text { Mastogloia elliptica; } \\
\text { Cosmioneis citriformis; } \\
\text { Haslea crucigera; } \\
\text { Pinnularia bertrandii }\end{array}$ \\
\hline $\mathrm{CJH}$ & $\begin{array}{l}\text { Bongpo-ri, Toseong-myeon, } \\
\text { Goseong-gun, Gangwon-do }\end{array}$ & $38^{\circ} 15^{\prime} 14.97^{\prime \prime}$ & $128^{\circ} 33^{\prime} 20.47^{\prime \prime}$ & Pinnularia nodosa var. percapitata \\
\hline $\mathrm{MH}$ & $\begin{array}{l}\text { Maeho-gil, Hyeonnam-myeon, } \\
\text { Yangyang-gun, Gangwon-do }\end{array}$ & $37^{\circ} 57^{\prime} 8.17^{\prime \prime}$ & $128^{\circ} 46^{\prime} 8.88^{\prime \prime}$ & Gyrosigma sinense \\
\hline GPW & $\begin{array}{l}\text { Gapyeong-ri, Sonyang-myeon, } \\
\text { Yangyang-gun, Gangwon-do }\end{array}$ & $38^{\circ} 6^{\prime} 8.46^{\prime \prime}$ & $128^{\circ} 38^{\prime} 50.58^{\prime \prime}$ & $\begin{array}{l}\text { Gomphonema guaraniarum; } \\
\text { Gomphonema italicum }\end{array}$ \\
\hline YGH & $\begin{array}{l}\text { Yeounpo-ri, Sonyang-myeon, } \\
\text { Yangyang-gun, Gangwon-do }\end{array}$ & $38^{\circ} 2^{\prime} 14.12^{\prime \prime}$ & $128^{\circ} 42^{\prime} 1.73^{\prime \prime}$ & $\begin{array}{l}\text { Navicula freesei; } \\
\text { Tryblionella littoralis var. tergestina }\end{array}$ \\
\hline
\end{tabular}

\subsection{Environmental Characteristics at the Sampling Sites}

The $\mathrm{pH}$ of the six sites ranged from 7.6 to 8.5 , showing a weakly basic range. The salinity of Gyeongpoho was in the range of 22.1-25.4 PSU and the electrical conductivity was higher than $35,000 \mu \mathrm{S} / \mathrm{cm}^{3}$. By contrast, Yeomgaeho and Cheonjinho had a salinity of less than 0.2 PSU and an electrical conductivity of less than $360 \mu \mathrm{S} / \mathrm{cm}^{3}$, which are more similar to the conditions of a freshwater environment (Table 2). 
Table 2. Field water quality of sampling sites.

\begin{tabular}{ccccccc}
\hline \multirow{2}{*}{ Site } & Year & Temperature $\left({ }^{\circ} \mathbf{C}\right)$ & $\begin{array}{c}\text { DO } \\
(\mathbf{m g} / \mathbf{L})\end{array}$ & $\begin{array}{c}\text { Conductivity } \\
\left(\mu \mathbf{S} / \mathbf{c m}^{3}\right)\end{array}$ & $\begin{array}{c}\text { Salinity } \\
(\mathbf{P S U})\end{array}$ & $\mathbf{p H}$ \\
\hline \multirow{2}{*}{$\mathrm{GPH}$} & 2018 & 20.8 & 8.5 & 35,261 & 22.1 & 8.4 \\
& 2019 & 16.0 & 10.4 & 39,820 & 25.4 & 8.5 \\
\hline \multirow{2}{*}{$\mathrm{HH}$} & 2018 & 17.8 & 11.0 & 8926 & 5.0 & 8.1 \\
& 2020 & 28.6 & - & 60 & 0.03 & 8.2 \\
\hline \multirow{2}{*}{$\mathrm{CJH}$} & 2019 & 16.0 & 9.5 & 360 & 0.2 & 8.7 \\
& 2020 & 14.0 & 9.2 & 152 & 0.1 & 8.1 \\
\hline \multirow{2}{*}{$\mathrm{MH}$} & 2018 & 20.2 & 10.9 & 15,969 & 9.4 & 8.1 \\
& 2020 & 15.8 & 10.8 & 5767 & 3.9 & 7.9 \\
\hline \multirow{2}{*}{$\mathrm{YGH}$} & 2020 & 13.3 & 16.2 & 1528 & 0.9 & 8.0 \\
\hline
\end{tabular}

\subsection{Species Descriptions}

\subsubsection{Cosmioneis citriformis R.L. Lowe \& A.R. Sherwood 2010}

Original description: Lowe and Sherwood 2010, p. 24, Figures 10-18 [31].

Dimensions: Length Range 29-33 $\mu \mathrm{m}$, width range 12-15 $\mu \mathrm{m}$, 17-20 striae in $10 \mu \mathrm{m}$.

Description: The valves are citriform with broadly rounded margins. The ends are short, narrow, and rostrate. The axial area is narrow and expands to a rounded central area. The proximal raphe ends are slightly expanded. The distal raphe ends are curved in the same direction. Internally, the raphe ends are anchor-shaped. Striae are punctate and radiate, curving from the margin towards the center of the valve. There are 17 striae in $10 \mu \mathrm{m}$ in the centre that become finer at the ends $(20$ in $10 \mu \mathrm{m})$. There are 16 areolae in $10 \mu \mathrm{m}$, which are round towards the valve ends, becoming transversely elongated near the centre (Figure 2A).
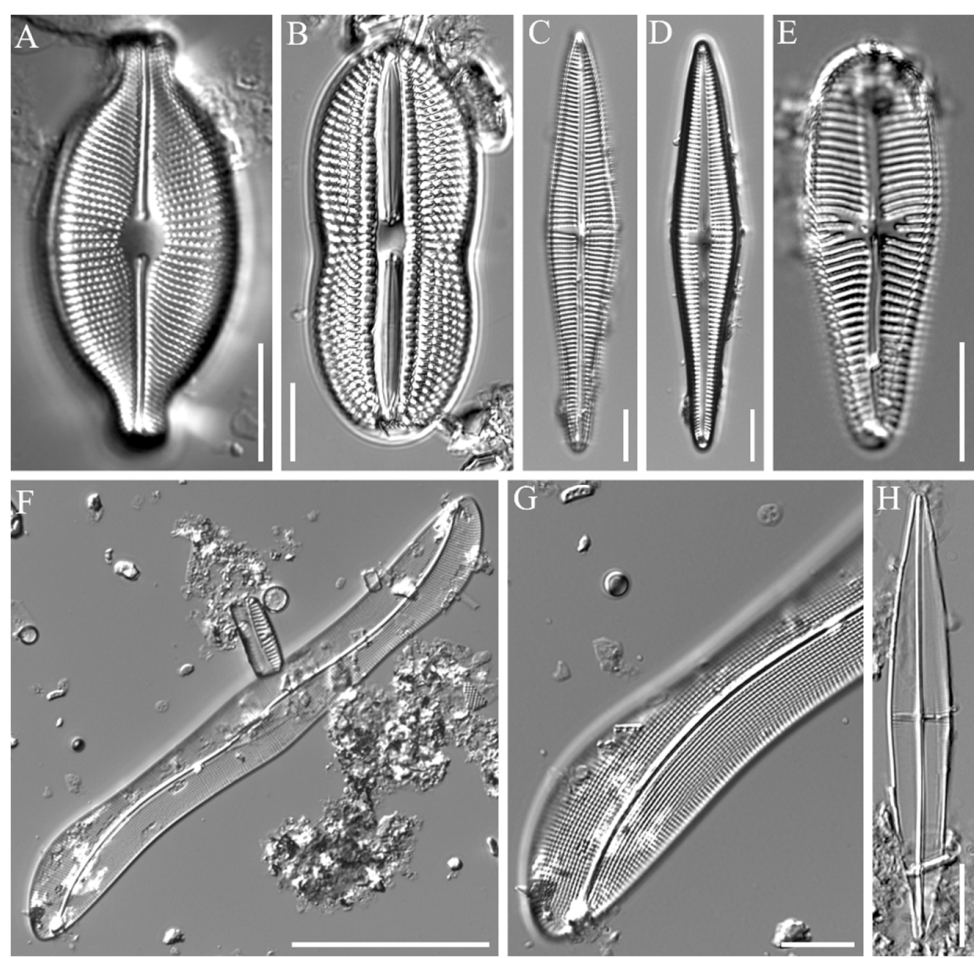

Figure 2. Light micrographs of diatoms. (A) Cosmioneis citriformis (B) Diploneis didyma (C,D) Gomphonema guaraniarum $(\mathbf{E})$ Gomphonema italicum $(\mathbf{F}, \mathbf{G})$ Gyrosigma sinense $(\mathbf{H})$ Haslea crucigera. Scale bars. 2-6, 8, 9:10 $\mu \mathrm{m} ; 7: 50 \mu \mathrm{m}$. 
Ecology and distribution: Distributed in freshwater habitats, benthic taxon. Hyangho lake is the focus in this study (Table 1).

\subsubsection{Diploneis didyma (Ehrenberg) Ehrenberg 1839}

Original description: Ehrenberg 1839, pls. 1-4 [32].

Basionym: Pinnularia didyma Ehrenberg 1844 [33].

Dimensions: Length Range $60-74 \mu \mathrm{m}$, width range $25-28 \mu \mathrm{m}, 8-10$ striae in $10 \mu \mathrm{m}$.

Description: The cells are solitary and free, the valves are elliptical or linear-elliptical, with or without a median constriction, and the apices are rounded or broadly cuneate. The central nodule is prominent, often large, quadrate, and strongly formed; the central area is small, reduced, and produces longitudinal extensions that are usually described as "horns" which lie on either side of the raphe and enclose it as solid ribs. Beyond the horns, there are thinner, usually narrow, and depressed areas, typically referred to as "furrows." These may be hyaline and structureless, may contain a row of large puncta, or may be crossed by faintly transverse costae. Beyond the furrows, on each side of the raphe, some specimens have a lunate area in each segment, which is usually referred to as the "lunula." This may be crossed by costae or alveoli, which may or may not bear a single or double row of puncta; these are frequently more developed and closer to the valve margin. In some specimens, transverse costae may be absent. Chromatophores are usually found as two deeply crenulated bodies that lie along the girdle. The valves are panduriform and slightly constricted in the middle, dividing the valve surface into two tongue-shaped segments. The central nodule is subquadrate or almost circular in some cases and protrudes to form two horns on either side of the raphe or median line, respectively. The valve surface is costate, transverse in the middle, but slightly curving. Radiating lines are found towards the apices that are crossed by numerous undulating longitudinal lines (Figure 2B).

Ecology and distribution: Distributed in marine-brackish habitats, benthic taxon. Gyeongpoho lake is the focus in this study (Table 1).

\subsubsection{Gomphonema guaraniarum Metzeltin \& Lange-Bertalot 2007}

Original description: Metzeltin \& Lange-Bertalot 2007,p. 147, pl. 212, Figures 9-14 [34].

Dimensions: Length Range 58-77 $\mu \mathrm{m}$, width range 10-12 $\mu \mathrm{m}$, 10-12 striae in $10 \mu \mathrm{m}$.

Description: The valves are rhombic-lanceolate, with less rounding of the apical and basal ends. The raphe-sternum is narrow and linear. The central area is unilaterally expanded, which is limited by a shortened median striae. The raphe is slightly sinuous with proximal ends that are punctuated and are slightly curved towards the stigma. The transapical striae slightly radiate parallel to the central region. Areolae are inconspicuous. There is a stigma at the end of the central stria. Under scanning electron microscopy (SEM), the stigma appears delicate and rounded, and striae are uniseriate with the areolae rounded to elongate longitudinally. The ends of the raphe dilate into pores, and the distal ends are curved, extending to the valve mantle. The pore field is formed by rounded poroids disposed on both sides of the terminal raphe fissure (Figure 2C,D).

Ecology and distribution: Distributed in freshwater habitats, epiphytic taxon. Gapyeongri Wetland is the focus in this study (Table 1).

\subsubsection{Gomphonema italicum Kützing 1844}

Original description: Kützing 1844, p. 85, pl. 30, Figure 75 [35].

Dimensions: Length Range 24-50 $\mu \mathrm{m}$, width range 10-12 $\mu \mathrm{m}$, 11-14 striae in $10 \mu \mathrm{m}$.

Description: The frustules in girdle view are wedge-shaped. The valves are strongly heteropolar and clavate, with the largest valve width in the upper valve half. The valves are tumid at the center, gradually narrowing towards the footpole and are slightly constricted towards the broadly rounded headpole. The axial area is moderately broad and linear. The central area is small and irregular in shape, bordered on each margin by a few irregularly shortened striae. One isolated pore is present at the end of the long central stria. The external isolated pore opening is small and rounded. The raphe is distinctly lateral and 
strongly undulated, with simple and slightly expanded proximal endings. The external proximal raphe endings are teardrop-shaped and are deflected towards the isolated pore. At the headpole, the distal raphe ends first deflect towards the pore-bearing side and then towards the opposite side, extending onto the valve mantle. At the footpole, the distal raphe dissects into a well-developed pore field. The transapical striae are not interrupted near the valve face/mantle junction but rather continue onto the valve mantle (Figure 2E).

Ecology and distribution: Distributed in freshwater and terrestrial habitats, epiphytic taxon. Gapyeongri Wetland is the focus in this study (Table 1).

\subsubsection{Gyrosigma sinense (Ehrenberg) Desikachary 1988}

Original description: Desikachary 1988, pp. 1-13, pls. 401-621 [36].

Basionym: Navicula sinensis Ehrenberg 1847 [37].

Description: The valves are linear-sigmoid, with inflated central and distal portions. The color in resin and standardized dark-field microscopy is bright blue. The raphe sternum has a double curvature and is rotated towards the internal central raphe node, strongly eccentric at the ends, where it is markedly displaced owing to its concavity. The central area is rhombic and rotated. The terminal areas are triangular and strongly displaced away from the apices so that they are in a completely lateral position. The central external raphe fissures have isomorphic deflection patterns crossing the striae. The apical structure shows one very long and one short apical microforamina segment on opposite sides of the raphe sternum (Figure 2F,G).

Ecology and distribution: Distributed in marine habitats, benthic taxon. Maeho lake is the focus in this study (Table 1).

\subsubsection{Haslea crucigera (W. Smith) Simonsen 1974}

Original description: Simonsen 1974, pp. 47 [38].

Basionym: Schizonema crucigerum W. Smith 1856 [39].

Dimensions: Length Range 95-97 $\mu \mathrm{m}$, width range 11-12 $\mu \mathrm{m}, 17-20$ striae in $10 \mu \mathrm{m}$.

Description: Living cells have slightly curved, narrowly rectangular frustules in girdle view. The valves are lanceolate to linear-lanceolate. Two band-like plastids lie against the girdle on each side of the cell. The internal margin of the plastids usually appears to be slightly undulating because of the presence of small, obliquely inserted, and rod-shaped pyrenoids. In the cleaned cells, the raphe appears straight and central. Transapical striae are visible under light microscopy and are crossed by more delicate longitudinal striae. The central two or three transapical virgae are thickened, forming a pseudostauros. Under SEM, the external valve surface is covered with closely spaced longitudinal strips of silica separated by narrow slits, which merge with a continuous peripheral slit near the apices. The external raphe fissures are slightly expanded and turn to one side centrally before sharply deflecting to the same side at the poles. Internally, the raphe slits open laterally in the raphe sternum, except at the center where the endings are straight and approximate, and at the apices, where they are slightly expanded in a slightly raised helictoglossa. An accessory rib on the primary side of the valve flanges over the raphe sternum, obscuring it for much of its length. The internal areola arrangement is similar to that of the other taxa, but with fewer longitudinal striae. On both sides of the raphe, the three central virgae thicken, forming a pseudostauros. The thickened virgae are fused with an accessory rib on the primary side of the valve and with a shorter thinner rib on the secondary side of the valve. The thickening of the virgae extends further across the valve and is more even compared with that in H. salstonica (Figure 2H).

Ecology and distribution: Distributed in brackish inland water habitats, benthic taxon. Hyangho lake is the focus in this study (Table 1).

\subsubsection{Mastogloia elliptica (C. Agardh) Cleve 1983}

Original description: (C. Agardh) Cleve 1983, pl. 185, Figures 24-27 [40].

Basionym: Frustulia elliptica C. Agardh 1824 [41]. 
Dimensions: Length Range 17-57 $\mu \mathrm{m}$, width range 8-12 $\mu \mathrm{m}, 15-18$ striae in $10 \mu \mathrm{m}$.

Description: The valves are elliptical to linear-elliptical with convex to nearly parallel sides, and blunt, obtusely rounded apices. The axial area is narrow and barely wider than the raphe, and the central area is circular. The raphe branches are lateral and sinuous, with weakly expanded proximal ends. There are numerous tecta of approximately the same size. The striae consist of single rows of areolae that radiate throughout (Figure $3 \mathrm{~A}-\mathrm{I}$ ). The raphe is a straight line or an undulate shape. The striae of Mastogloia elliptica are parallel in shape, and the raphe is straight (Figure 3A). In addition, due to the complex valvocopula structure, pertaca and striae are visible at the same time (Figure 3B-D), with seven symmetrical pertaca on each side (Figure 3E-I).
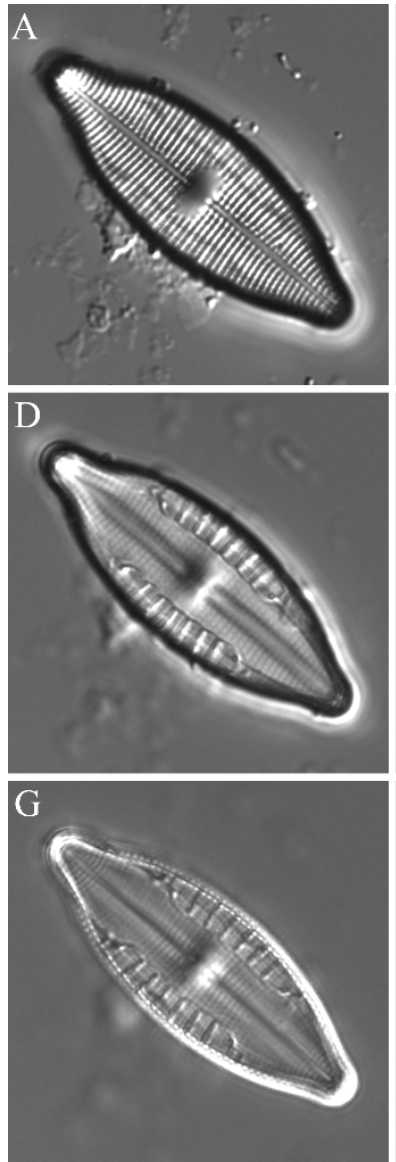
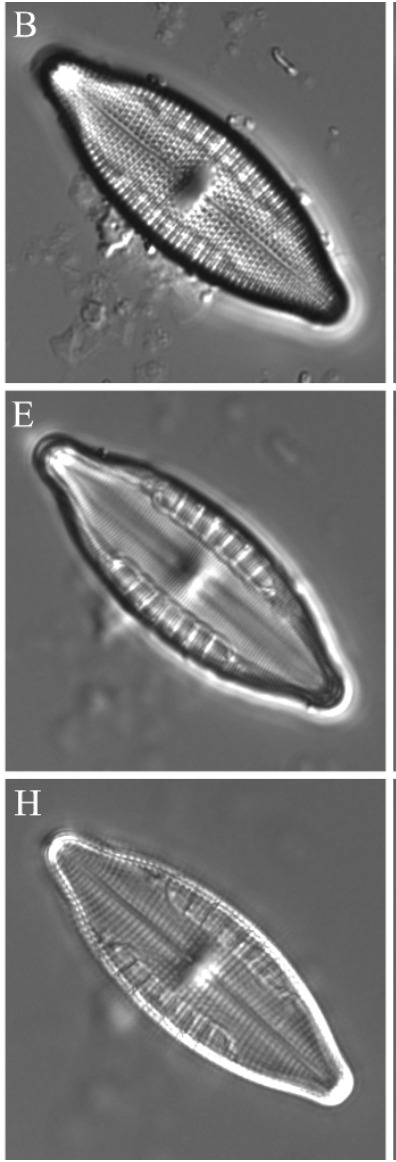
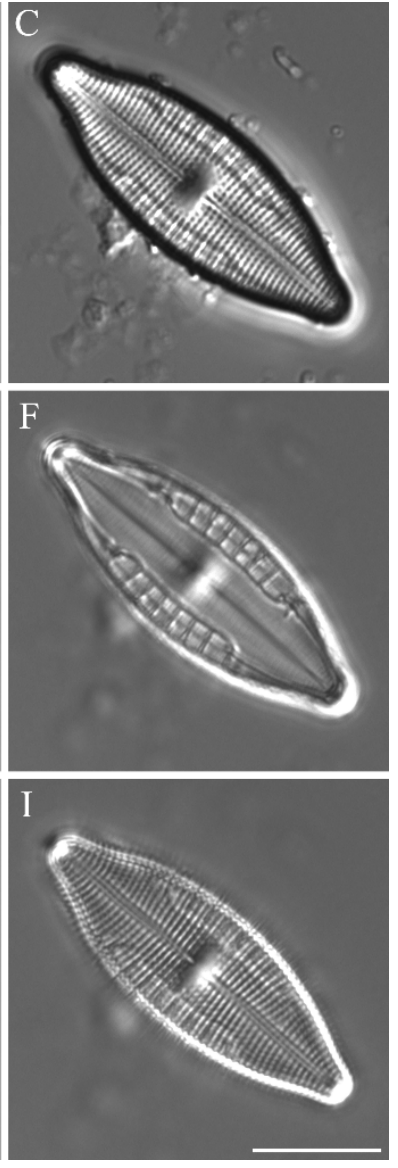

Figure 3. Light micrographs of Mastogloia elliptica in various depth of field ranges in microscope. (A-C,I) surface focus of valve face with uniseriate striae $(\mathbf{D}-\mathbf{H})$ Deeper focus with similar sized numerous partecta (arrows). Scale bar: $10 \mu \mathrm{m}$.

Ecology and distribution: Distributed in marine and freshwater habitats, benthic taxon. Hyangho lake is the focus in this study (Table 1).

\subsubsection{Navicula freesei R.M. Patrick \& Freese 1961}

Original description: Patrick, R.M. \& Freese 1961, p. 206, pl. 2, Figure 14 [42].

Dimensions: Length Range 61-77 $\mu \mathrm{m}$, width range 13-15 $\mu \mathrm{m}, 8-9$ striae in $10 \mu \mathrm{m}$.

Description: The valves are lanceolate with rounded apices. The striae are radiated at the center, and are parallel and slightly convergent at the apices. The central area is asymmetrically rounded, whereas the axial area is narrow and straight. Striae on one or both sides of the central area are irregularly spaced. The raphe is lateral and straight. The distal raphe fissures form curved hooks onto the mantle. The proximal raphe ends form an 
elongated central poroid. A thickened central nodule is evident. Girdle bands have not yet been defined (Figure $4 \mathrm{~A}$ ).
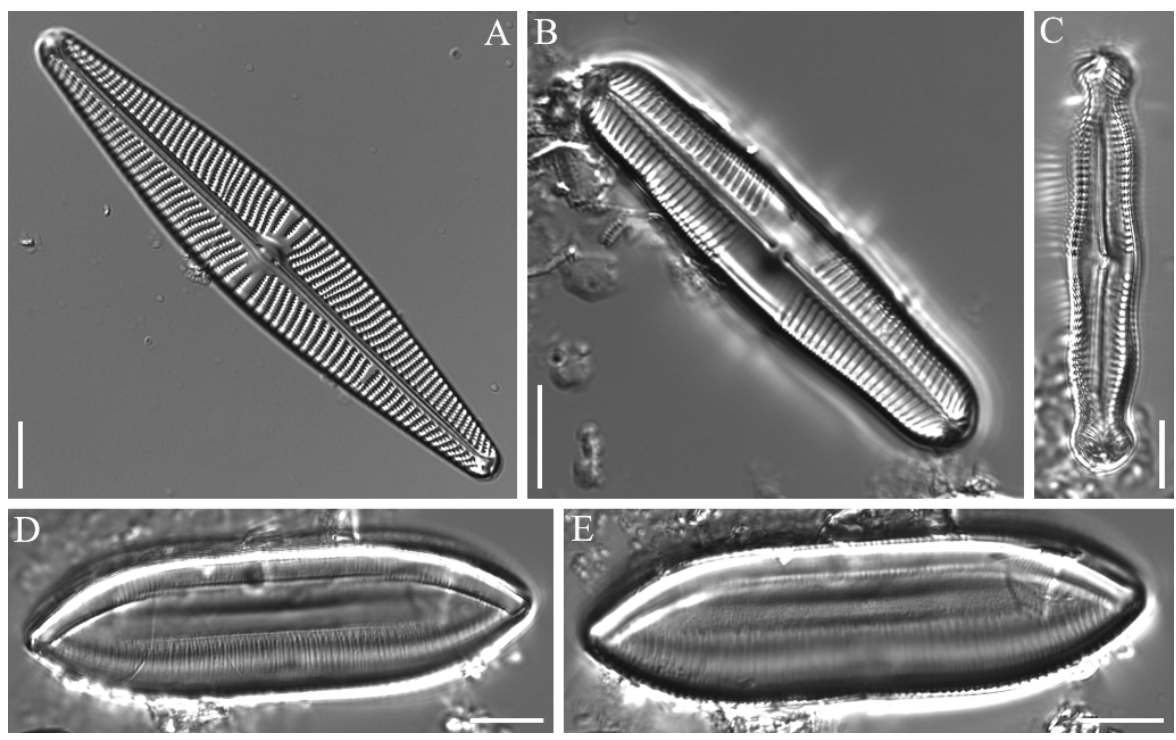

Figure 4. Light micrographs of diatoms. (A) Navicula freesei (B) Pinnularia bertrandii (C) Pinnularia nodosa var. percapitata (D,E) Tryblionella littoralis var. tergestina. Scale bars:10 $\mu \mathrm{m}$.

Ecology and distribution: Distributed in freshwater habitats, benthic taxon. Yeomgaeho is the focus in this study (Table 1).

\subsubsection{Pinnularia bertrandii Krammer 2000}

Original description: Krammer 2000, pp. 122, 226, pl. 91, Figures 22-30 [43].

Dimensions: Length Range $14-27 \mu \mathrm{m}$, width range 4-6 $\mu \mathrm{m}, 17-18$ striae in $10 \mu \mathrm{m}$.

Description: The valves are linear-elliptical to linear-lanceolate with weakly convex sides. The ends are subcapitate nearly covering the breadth of the valve body, which are broadly rounded. The raphe is filiform to slightly lateral, the central pores are small and slightly laterally bent, and the terminal fissures are distinct. The axial area is narrowed and the lanceolate is widened from the ends to the fascia. The striae in the middle weakly radiate and moderately converge at the ends and longitudinal bands are absent (Figure 4B).

Ecology and distribution: Distributed in freshwater habitats, benthic taxon. Hyangho lake is the focus in this study (Table 1).

\subsubsection{Pinnularia nodosa var. percapitata Krammer 2000}

Original description: Krammer 2000, pp. 57, Figures 26:9-12; 27:9, 10 [43].

Dimensions: Length Range 47-61 $\mu \mathrm{m}$, width range 9-10 $\mu \mathrm{m}, 8-10$ striae in $10 \mu \mathrm{m}$.

Description: The valves are linear with triundulate margins. In the largest specimens, the central undulation is wider than the distal undulations. Apices are distinctly capitated. Axial areas are about one-third of the valve's width and widen from the apices towards the valve center. The central area is a bilateral fascia. The surface of the valve is mottled along either side of the raphe and continues into the central area. The raphe is straight. The proximal raphe ends are bent to one side and terminate in small, tear-shaped pores. Distal raphe fissures are shaped like question marks. The striae are weakly radiated at the valve center and become strongly convergent at the apices (Figure 4C).

Ecology and distribution: Distributed in freshwater habitats, benthic taxon. Chunjinho lake is the focus in this study (Table 1). 


\subsubsection{Tryblionella littoralis var. tergestina (Grunow) Snoeijs 1998}

Original description: Snoeijs \& Balashova 1998, pp. 1-144, Figure 1, pls. 101 [44].

Basionym: Nitzschia littoralis var. tergestina Grunow 1880 [45].

Dimensions: Length Range 30-100 $\mu \mathrm{m}$, width range 12-30 $\mu \mathrm{m}, 30-38$ striae in $10 \mu \mathrm{m}$.

Description: The valves are broadly elliptical-lanceolate to linear-elliptical, with a very slight central constriction of the keel. Apices are cuneate, narrowed, and rounded. Striae are difficult to resolve under light microscopy (Figure 4D,E).

Ecology and distribution: Distributed in freshwater habitats, benthic taxon. Yeomgaeho is the focus in this study (Table 1).

\section{Discussion}

Reservoir salt concentrations fluctuate over time; thus, lagoons create a unique ecosystem by mixing inland freshwater with intrusions of seawater. Accordingly, freshwater life with resistance to salt mixes with marine life in the lagoon ecosystem [3]. In this study, 11 previously unrecorded diatom species were discovered in six lagoons in Korea. Diploneis didyma was detected in Gyeongpoho. This species is mainly found in harbors but has also been reported in freshwater. At the time of the survey, Gyeongpoho had a high electrical conductivity above $30,000 \mu \mathrm{S} / \mathrm{cm}^{3}$ and the salinity was $22 \mathrm{PSU}$, demonstrating environmental conditions similar to those of seawater (Tables 2 and 3). Cosmioneis predominantly inhabits brackish water zones [46-48] but has also been found in alkaline freshwater environments [30,49]. We detected Cosmioneis citriformis in Hyangho, which has very low salinity (0.03 PSU) and an electrical conductivity of $60 \mu \mathrm{S} / \mathrm{cm}^{3}$, demonstrating similarity to the conditions of a freshwater environment. However, the measurements taken in the survey of 2018 showed a salinity of $5.0 \mathrm{PSU}$ and an electrical conductivity of $8925 \mu \mathrm{S} / \mathrm{cm}^{3}$ at this site, and C. citriformis was not found at that time (Tables 2 and 3). Haslea crucigera is a benthic species and is mainly found in high-salinity water [50]; however, during the 2018 survey, the salinity at Hyangho was 5.0 PSU and the electrical conductivity was $8926 \mu \mathrm{S} / \mathrm{cm}^{3}$. Therefore, $H$. crucigera appears to prefer a water environment with some salt, although the salinity at this site remained lower than that of seawater throughout the survey period (Tables 2 and 3). Pinnularia bertrandii is a benthic species that is mainly detected in freshwater environments [51]. During the survey in 2020, the environmental conditions of the water at Hyangho were similar to those of a freshwater environment with a salinity of $0.03 \mathrm{PSU}$ and an electrical conductivity of $60 \mu \mathrm{S} / \mathrm{cm}^{3}$ (Tables 2 and 3). Pinnularia nodosa var. percapitata is also a benthic species that is mainly found in freshwater environments, mostly in streams, reservoirs, and small lakes, with a $\mathrm{pH}$ ranging from 6.1 to 7.8 (slightly acidic to neutral), and an electric conductivity from 22 to $169 \mu \mathrm{S} / \mathrm{cm}^{3}$ [43]. At the time of sampling, the water of Chunjinho had very low salinity of $0.1-0.2 \mathrm{PSU}$, with a $\mathrm{pH}$ of 8.1 to 8.7 and a relatively low electrical conductivity of $152-360 \mu \mathrm{S} / \mathrm{cm}^{3}$ (Tables 2 and 3). Gyrosimga sinense is a benthic species that has a seawater-based and widespread distribution under high water temperatures [52]. At the time of sampling, the water temperature of Maeho was relatively high, ranging from $15.8^{\circ} \mathrm{C}$ to $20.2{ }^{\circ} \mathrm{C}$, with salinity ranging from 3.9 to $9.4 \mathrm{PSU}$, and electrical conductivity ranging from 5767 to $15,969 \mu \mathrm{S} / \mathrm{cm}^{3}$ (Tables 2 and 3). The genus Gomphonema is mostly attachable and is mainly found in freshwater environments, representing the largest genus in freshwater environments among diatoms of the world's most broadly distributed species [53,54]. In particular, Gomphonema can grow by attaching to aquatic plants because of the mucous stem secreted from the pore fields at the end of the valve $[30,55,56]$. G. guaraniarum is a freshwater species and its ecological properties are rarely described in the literature. G. italicum is also a freshwater species with a relatively high electrical conductivity of $13,250 \mu \mathrm{S} / \mathrm{cm}^{3}$ and is known to emerge in environments with a weakly basic $\mathrm{pH}$ [57]. In this study, G. guaraniarum and G. italicum were detected at the Gapyeong-ri wetland, with a water temperature of $13.3^{\circ} \mathrm{C}$, a DO of $16.2 \mathrm{mg} / \mathrm{L}$, a $\mathrm{pH}$ of 8.0, a salinity of $0.9 \mathrm{PSU}$, and an electrical conductivity of $1528 \mu \mathrm{S} / \mathrm{cm}^{3}$, indicating that they inhabit an environment with freshwater-like conditions (Tables 2 and 3). Navicula freesei was found in freshwater and brackish environments, mainly with neutral 
to weakly basic conditions [42]. Tryblionella littoralis var. tergestina is an epipelic diatom and marine species [44]. In this study, these two species were identified at Yeomgaeho, with the water environment being similar to a freshwater environment at the time of sampling (a salinity $0.1 \mathrm{PSU}$, a pH of 7.6, and an electrical conductivity of $288 \mu \mathrm{S} / \mathrm{cm}^{3}$ ) (Tables 2 and 3). This suggests that Tryblionella littoralis var. tergestina adapted to the desalinated lagoon. Mastogloia is a benthic and epiphytic diatom, which was identified in both freshwater and marine environments; however, most species of this genus appear in marine environments and prefer weakly basic water bodies [58,59]. Patrick and Reimer [60] report M. elliptica as a halophilic to mesohalobic taxon characteristic of coastal areas, but is also found in inland lakes with some salinity. In Europe, Krammer and Lange-Bertalot [61] report $M$. elliptica from brackish waters in coastal areas and from saline inland waters. At the time of sampling, the $\mathrm{pH}$ of Hyangho was 8.2 and the salinity was 0.03 PSU, exhibiting a water environment close to that of the freshwater environment (Tables 2 and 3). Mastogloia has oval to linear oval convex valves, with complex silica chambers on both sides, called pertaca, that secrete mucus, and living cells that have two plastids [39,62]. This genus appears to be closely related to the genus Aneumastus but with a more complex valvocopula [63]. Patrick and Reimer [60] reported that M. elliptica is a halophilic to mesohalobic taxon characteristic of coastal areas but is also found in inland lakes with some salinity. In Europe, Krammer and Lange-Bertalot [61] reported M. elliptica from brackish waters in coastal areas and from saline inland waters.

Table 3. Information of New record diatoms in Korea.

\begin{tabular}{|c|c|c|c|c|c|c|}
\hline \multirow{2}{*}{ No. } & \multirow{2}{*}{ Species } & \multirow{2}{*}{ Habitat } & \multirow{2}{*}{ Distribution } & \multicolumn{2}{|c|}{ This Study } & \multirow{2}{*}{ Reference } \\
\hline & & & & Salinity & Habitat & \\
\hline 1 & Diploneis didyma & Benthic & $\begin{array}{c}\text { Marine } \\
\text { Freshwater }\end{array}$ & $22.1-25.4$ & Epilithic & {$[64,65]$} \\
\hline 2 & Mastogloia elliptica & $\begin{array}{c}\text { Benthic } \\
\text { Epiphytic }\end{array}$ & $\begin{array}{c}\text { Marine } \\
\text { Freshwater }\end{array}$ & $0.03-5.0$ & Epilithic & [59] \\
\hline 3 & Cosmioneis citriformis & Benthic & Freshwater & $0.03-5.0$ & Epilithic & [31] \\
\hline 4 & Haslea crucigera & Benthic & Marine & $0.03-5.0$ & Epilithic & [50] \\
\hline 5 & Pinnularia bertrandii & Benthic & Freshwater & $0.03-5.0$ & Epilithic & [51] \\
\hline 6 & Pinnularia nodosa var. percapitata & Benthic & Freshwater & $0.1-0.2$ & Epilithic & [66] \\
\hline 7 & Gyrosigma sinense & Benthic & Marine & $3.9-9.4$ & Epilithic & [52] \\
\hline 8 & Gomphonema guaraniarum & Benthic & Freshwater & 0.9 & Epilithic & {$[67]$} \\
\hline 9 & Gomphonema italicum & Benthic & $\begin{array}{c}\text { Freshwater } \\
\text { Terrestrial }\end{array}$ & 0.9 & Epilithic & [67] \\
\hline 10 & Navicula freesei & Benthic & Freshwater & 0.1 & Epilithic & [42] \\
\hline 11 & Tryblionella littoralis var. tergestina & Benthic & Marine & 0.1 & Epilithic & [44] \\
\hline
\end{tabular}

Author Contributions: Data curation, formal analysis, writing-original draft, and writing-review and editing, D.K. and S.D.L.; funding acquisition, C.S.L.; field investigation, D.K., M.P., C.S.L. and S.D.L.; writing-review and editing, D.K., M.P., C.S.L., C.P. and S.D.L. All authors have read and agreed to the published version of the manuscript.

Funding: This work was supported by grants from the Nakdonggang National Institute of Biological Resources (NNIBR) (NNIBR202101103) projects.

Institutional Review Board Statement: Not applicable.

Informed Consent Statement: Not applicable.

Data Availability Statement: Not applicable.

Conflicts of Interest: The authors declare no conflict of interest. 


\section{References}

1. Dominguez, J.M.; Martin, L.; Bittencourt, A.C. Sea-Level History and Quaternary Evolution of River Mouth-Associated Beachridge Plains Along the East-Southeast Brazilian Coast: A Summary. In Sea-Level Fluctuation and Coastal Evolution; Nummedal, D., Pilkey, O.H., Howard, J.D., Price, W.A., Eds.; SEPM Special Publication: Broken Arrow, OK, USA, 1987; Volume 41, pp. 115-127.

2. Müller, A.; Mathesius, U. The palaeoenvironments of coastal lagoons in the southern Baltic Sea, I. The application of sedimentary Corg/N ratios as source indicators of organic matter. Palaeogeogr. Palaeoclimatol. Palaeoecol. 1999, 145, 1-16. [CrossRef]

3. Hwang, S.I.; Yoon, S.O. Geomorphic characteristics of coastal lagoons and river basins, and sedimentary environment at river mouths along the middle east coast in the Korean peninsular. Korean J. Geomorphol. Assoc. 2008, 15, 17-33.

4. Moon, B.R.; Jeon, H.J.; Jeon, S.L.; Lee, J.S.; Shin, J.E.; Ahn, J.H.; Yang, Y.W.; Hyun, M.S.; Kim, M. Seasonal Variations of Water Quality and Phytoplankton of 4 Lagoons in the East Coast of Korea. Int. J. Environ. Sci. Technol. 2015, 24, 1101-1121.

5. Yum, J.G.; Takemura, K.; Tokuoka, T.; Yu, K.M. Holocene environmental changes of the Hwajinpo Lagoon on the eastern coast of Korea. J. Paleolimnol. 2003, 29, 155-166. [CrossRef]

6. Kwon, S.Y.; Lee, J.I.; Kim, D.J.; Kim, B.C.; Heo, W.M. The limnological survey of a coastal lagoon in Korea (3): Lake Hwajinpo. Korean J. Ecol. Environ. 2004, 37, 12-25.

7. Heo, W.M.; Kim, B.C.; Jun, M.S. Evaluation of eutrophication of lagoons in the eastern coast of Korea. Korean J. Limnol. 1999, 32, $141-151$.

8. Kwon, S.Y.; Lee, J.I.; Kim, D.J.; Kim, B.C.; Heo, W.M. The Limnological survey of a coastal lagoon in Korea (2): Lake Hyangho. Korean J. Ecol. Environ. 2004, 37, 1-11.

9. Kim, H.Y. Change of the vegetation structure according to hydrosere processes and the evaluation of successional state of the 18 lagoon located in the east coastal region, Korea. Master's Thesis, Gangneung University, Gangneung, Korea, 2009 ; pp. 1-137.

10. Jeong, Y.I.; Hong, B.R.; Kim, Y.C.; Lee, K.S. Distribution, life history and growth characteristics of the Utricularia japonica Makino in the east coastal lagoon, Korea. Korean J. Ecol. Environ. 2016, 49, 110-123. [CrossRef]

11. Kim, T.K.; Kim, C.S. An Analysis of Factors Influencing the Landscape of Gyeong Po Lake and the Establishment of Criteria for Height Control. J. Korean Inst. Landsc. Archit. 2009, 37, 104-113.

12. Park, S.D.; Lee, S.; Shin, S.S.; Yoon, B.M. Effects of Operation of the Kyeongpo Retarding Basin on Flood Water Levelin Kyeongpo Lake. J. Wet. Res. 2016, 18, 413-423. [CrossRef]

13. Yoon, S.; Hwang, S.; Park, C.; Jin, M. Landscape changes during the 20th century of Ssangho, Gapy-eongri wetland, Gunggaeho and Yeongaeho, Yang yang-gun, Gangwon province. J. Korean Geomorph. Assoc. 2010, 17, 41-52.

14. Falcão, M.; Vale, C. Nutrient dynamics in a coastal lagoon (Ria Formosa, Portugal): The importance of lagoon-sea water exchanges on the biological productivity. Cienc. Mar. 2003, 29, 425-433. [CrossRef]

15. Bizzarro, J.J. A review of the physical and biological characteristics of the Bahia Magdalena lagoon complex (Baja California Sur, Mexico). Bull. South. Calif. Acad. Sci. 2008, 107, 1-24. [CrossRef]

16. Salomoni, S.E. Diatomáceas epilíticas indicadoras da qualidade de água na bacia do Rio Gravataí, Rio Grande do Sul, Brasil. Ph.D. Thesis, Ppgern Ufscar, São Carlos, São Paulo, Brasil, 2004; pp. 1-230.

17. Cho, I.H.; Kim, H.K.; Lee, M.H.; Kim, Y.J.; Lee, H.; Kim, B.H. The Effect of Monsoon Rainfall Patterns on Epilithic Diatom Communities in the Hantangang River, Korea. Water 2020, 12, 1471. [CrossRef]

18. Wunsam, S.; Cattaneo, A.; Bourassa, N. Comparing diatom species, genera and size in biomonitoring: A case study from streams in the Laurentians (Quebec, Canada). Freshwater Biol. 2002, 47, 325-340. [CrossRef]

19. Joung, S.H.; Park, H.K.; Lee, H.J.; Lee, S.H. Effect of climate change for diatom bloom at winter and spring season in Mulgeum Station of the Nakdong River, South Korea. J. Korean Soc. Water Environ. 2013, 29, 155-164.

20. Sylvestre, F.; Beck-Eichler, B.; Duleba, W.; Debenay, J.P. Modern benthic diatom distribution in a hypersaline coastal lagoon: The Lagoa de Araruama (RJ), Brazil. Hydrobiologia 2001, 443, 213-231. [CrossRef]

21. Park, J.S.; Yun, S.M.; Lee, S.D.; Lee, J.B.; Lee, J.H. New Records of the Diatoms (Bacillariophyta) in the Brackish and Coastal Waters of Korea. Korean J. Environ. Biol. 2017, 35, 215-226. [CrossRef]

22. Lee, H.; Yun, S.M.; Lee, J.Y.; Lee, S.D.; Lim, J.; Cho, P.Y. Late Holocene climate changes from diatom records in the historical Reservoir Gonggeomji, Korea. J. Appl. Phycol. 2018, 30, 3205-3219. [CrossRef]

23. Lee, S.D.; Lee, H.; Park, J.; Yun, S.M.; Lee, J.Y.; Lim, J.S.; Park, M.R.; Kwon, D.Y. Late Holocene diatoms in sediment cores from the Gonggeomji Wetland in Korea. Diatom Res. 2020, 35, 195-229. [CrossRef]

24. Park, J.S.; Lee, S.D.; Kang, S.E.; Lee, J.H. New records of the marine pennate diatoms in Korea. J. Ecol. Environ. 2014, 37, 231-244. [CrossRef]

25. Lee, J.H.; Park, J.S. Newly recorded diatom species in marine and fresh water of Korea. J. Ecol. Environ. 2015, 38, 545-562. [CrossRef]

26. Sournia, A. Quelques nouvelles données sur le phytoplancton marin et la production primaire à Tuléar (Madagascar). Hydrobiologia 1968, 31, 545-560. [CrossRef]

27. Hasle, G.R.; Fryxell, G.A. Diatoms: Cleaning and mounting for light and electron microscopy. Trans. Am. Microsc. Soc. 1970, 89, 469-474. [CrossRef]

28. Anonymous. Proposals for a standardization of diatom terminology and diagnoses. Nova Hedwigia, Beiheft. 1975, 53, 323-354.

29. Ross, R.; Cox, E.J.; Karayeva, N.I.; Mann, D.G.; Paddock, T.B.B.; Simonsen, R.; Sims, P.A. An amended terminologyfor the siliceous components of the diatom cell. Nova Hedwig. Beiheft. 1979, 64, 513-533. 
30. Round, E.E.; Crawford, R.M.; Mann, D.G. The Diatoms. Biology and Morphology of the Genera; Cambridge University Press: Cambridge, UK, 1990; pp. 1-747.

31. Lowe, R.L.; Sherwood, A.R. Three new species of Cosmioneis (Bacillariophyceae) from Hawaii. Proc. Acad. Nat. Sci. Phila. 2010, 160, 21-28. [CrossRef]

32. Ehrenberg, C.G. Über die Bildung der Kreidefelsen und des Kreidemergels durch unsichtbare Organismen. In Abhandlungen der Königlichen Akademie der Wissenschaften zu Berlin; Physikalische Klasse: Göttingen, Germany, 1839; Volume 1838, pp. 59-147, pls.

33. Ehrenberg, C.G. Mittheilung über 2 neue Lager von Gebirgsmassen aus Infusorien als Meeres-Absatz in Nord-Amerika und eine Vergleichung derselben mit den organischen Kreide-Gebilden in Europa und Afrika. In Bericht über die zur Bekanntmachung geeigneten Verhandlungen der Königlich-Preussischen Akademie der Wissenschaften zu Berlin; Physikalische Klasse: Göttingen, Germany, 1844; Volume 1844, pp. 57-97.

34. Metzeltin, D.; Lange-Bertalot, H. Tropical Diatoms of South America II. Special remarks on biogeography disjunction. Iconogr. Diatomol. 2007, 18, 1-877.

35. Kützing, F.T. Die Kieselschaligen Bacillarien oder Diatomeen, Nordhausen: Zu finden bei W.: Köhne, Germany, 1844; pp. [i-vii], [1]-152, pls 1-30.

36. Desikachary, T.V. Marine diatoms of the Indian Ocean region. In Atlas of Diatoms; Madras: Madras Science Foundation: Tamil Nadu, India, 1988; Volume V, pp. 1-13.

37. Ehrenberg, C.G. Mittheilung uber vor Kurzem von dem Preuß. Seehandlungs Schiffe, der Adler, aus Canton Mitgebrachte Verkaufliche Chinesische Blumen-Cultur-Erde; Bericht über die zur Bekanntmachtung geeigneten Verhandlungen der Koniglich Preussischen Akademie der Wissenschaften zu Berlin: Berlin, Germany, 1847; pp. 476-485.

38. Simonsen, R. The diatom plankton of the Indian Ocean Expedition of R/V Meteor 1964-5. Meteor Forschungsergebnisse, Reihe D Biologie 1974, 19, 1-107.

39. Smith, W. A Synopsis of the British Diatomaceae; with Remarks on Their Structure, Functions and Distribution; and Instructions for Collecting and Preserving Specimens. A-E; John van Voorst: London, UK, 1856; Volume 2, pp. [i-vi]-xxix, pls 32-60, 61-62.

40. Schmidt, A. Atlas der Diatomaceen-kunde; ser. IV: Heft 47; O.R. Reisland: Leipzig, Germany, 1983; pp. $185-188$.

41. Agardh, C.A. Systema Algarum; Literis Berlingianis [Berling]: Lundae, Sweden, 1824; pp. [i]-xxxvii, [1]-312.

42. Patrick, R.M.; Freese, L.R. Diatoms (Bacillariophyceae) from Northern Alaska. Proc. Acad. Nat. Sci. Phila. 1961, 112, 129-293.

43. Krammer, K. The genus Pinnularia. In Diatoms of the European Inland Waters and Comparable Habitats; Lange-Bertalot, H., Ed.; Ruggell: A.R.G. Gantner Verlag K.G.: Berlin/Heidelberg, Germany, 2000; Volume 1, pp. 1-703.

44. Snoeijs, P.; Balashova, N. Intercalibration and distribution of diatom species in the Baltic Sea. In The Baltic Marine Biologists Publication No. 16e; Opulus Press: Uppsala, Sweden, 1998; Volume 5, pp. 1-144.

45. Cleve, P.T.; Grunow, A. Beiträge zur Kenntniss der arctischen Diatomeen. Kongliga Svenska Vetenskaps-Akademiens Handlingar 1880, $17,1-121$.

46. Hällfors, G. Checklist of Baltic Sea Phytoplankton Species (Including Some Heterotrophic Protistan Groups); Helsinki Commission, Baltic Marine Environment Protection Commission: Helsinki, Finland, 2004; pp. 1-210.

47. Sylvestre, F.; Guiral, D.; Debenay, J.P. Modern diatom distribution in mangrove swamps from the Kaw Estuary (French Guiana). Mar. Geol. 2004, 208, 281-293. [CrossRef]

48. Marshall, H.G.; Burchardt, L.; Lacouture, R. A review of phytoplankton composition within Chesapeake Bay and its tidal estuaries. J. Plank. Res 2005, 27, 1083-1102. [CrossRef]

49. Kociolek, J.P.; Spaulding, S.A. Symmetrical naviculoid diatoms. In Freshwater Algae of the United States; Sheath, B., Wher, J., Eds.; Academic Press: Cambridge, MA, USA, 2003; pp. 637-653.

50. Massé, G.; Rincé, Y.; Cox, E.J.; Allard, G.; Belt, S.T.; Rowland, S.J. Haslea salstonica sp. nov. and Haslea pseudostrearia sp. nov.(Bacillariophyta), two new epibenthic diatoms from the Kingsbridge estuary, United Kingdom. Comptes Rendus de l'Académie des Sciences-Series III-Sciences de la Vie 2001, 324, 617-626. [CrossRef]

51. Kheiri, S.; Solak, C.N.; Edlund, M.B.; Spaulding, S.; Nejadsattari, T.; Asri, Y.; Hamdi, S.M.M. Biodiversity of diatoms in the Karaj River in the Central Alborz, Iran. Diatom Res. 2018, 33, 355-380. [CrossRef]

52. Jahn, R.; Sterrenburg, F.A. Gyrosigma sinense (Ehrenberg) desikachary: Typification and emended species description. Diatom Res. 2003, 18, 61-67. [CrossRef]

53. Zhang, W.; Xu, X.Y.; Kociolek, J.P.; Wang, L.Q. Gomphonema shanghaiensis sp. nov., a new diatom species (Bacillariophyta) from a river in Shanghai, China. Phytotaxa 2016, 278, 29-38. [CrossRef]

54. Abarca, N.; Zimmermann, J.; Kusber, W.H.; Mora, D.; Van, A.T.; Skibbe, O.; Jahn, R. Defining the core group of the genus Gomphonema Ehrenberg with molecular and morphological methods. Bot. Lett. 2020, 167, 114-159. [CrossRef]

55. Wojtal, A. Diatoms of the genus Gomphonema Ehr. [Bacillariophyceae] from a karstic stream in the Krakowsko-Czestochowska Upland. Acta Soc. Bot. Pol. 2003, 72. [CrossRef]

56. Cox, E.J. Diatoms, Diatomeae (Bacillariophyceae sl, Bacillariophyta). Syllabus Plant Fam. 2015, 2, 64-103.

57. Rybak, M.; Noga, T.; Poradowska, A. Diversity in anthropogenic environment-permanent puddle as a place for development of diatoms. J. Ecol. Eng. 2019, 20, 165-174. [CrossRef]

58. Krammer, K. Bacillariophyceae. I. Teil. Naviculaceae. In Susswasserflora von Mitteleuropa. Springer: Berlin/Heidelberg, Germany, 1986; Volume 2, 876p. 
59. Vidaković, D.; Ćirić, M.; Krizmanić, J. First finding of a genus Haslea Simonsen in Serbia and new diatom taxa for the country's flora in extreme and unique habitats in the Vojvodina Province. Bot. Serbica 2020, 44, 3-9. [CrossRef]

60. Patrick, R.; Reimer, C.W. The diatoms of the United States. Exclusive of Alaska and Hawaii. Volume 1: Fragilariaceae, Eunotiaceae, Achnanthaceae, Naviculaceae. Monogr. Acad. Nat. Sci. Phila. 1966, 13, 1-688.

61. Krammer, K.; Lange-Bertalot, H. Bacillariophyceae. 1. Teil: Naviculaceae. In Süsswasserflora von Mitteleuropa, Band 2/1; Ettl, H., Gerloff, J., Heynig, H., Mollenhauer, D., Eds.; Gustav Fisher Verlag: Jena, Germany, 1986; pp. 1-876.

62. Pennesi, C.; Poulin, M.; De Stefano, M.; Romagnoli, T.; Totti, C. New insights to the ultrastructure of some marine Mastogloia species section Sulcatae (Bacillariophyceae), including M. neoborneensis sp. nov. Phycologia 2011, 50, 548-562. [CrossRef]

63. Maltsev, Y.; Andreeva, S.; Podunay, J.; Kulikovskiy, M. Description of Aneumastus mongolotusculus sp. nov.(Bacillariophyceae, Mastogloiales) from Lake Hovsgol (Mongolia) on the basis of molecular and morphological investigations. Nova Hedwig. 2019, 148, 21-33. [CrossRef]

64. Donadel, L.; Torgan, L. Subtropical Coastal Lagoon from Southern Brazil: Environmental Conditions and Phytobenthic Community Structure. In Lagoon Environments Around the World-A Scientific Perspective; IntechOpen: London, UK, 2019 ; pp. 189-205.

65. Cartaxana, P.; Ruivo, M.; Hubas, C.; Davidson, I.; Serôdio, J.; Jesus, B. Physiological versus behavioral photoprotection in intertidal epipelic and epipsammic benthic diatom communities. J. Exp. Mar. Biol. Ecol. 2011, 405, 120-127. [CrossRef]

66. Genkal, S.I.; Yarushina, M.I. Materials on the flora of Bacillariophyta in aquatic ecosystems of the Yarayakha River basin (Yamal Peninsula). Contemp. Probl. Ecol. 2016, 9, 306-317. [CrossRef]

67. Medeiros, G.; Amaral, M.W.W.; Ferreira, P.C.; Ludwig, T.V.; Bueno, N.C. Gomphonema Ehrenberg (Bacillariophyceae, Gomphonemataceae) do rio São Francisco Falso, Paraná, Brasil. Biota Neotrop. 2018, 18, e20180568. [CrossRef] 